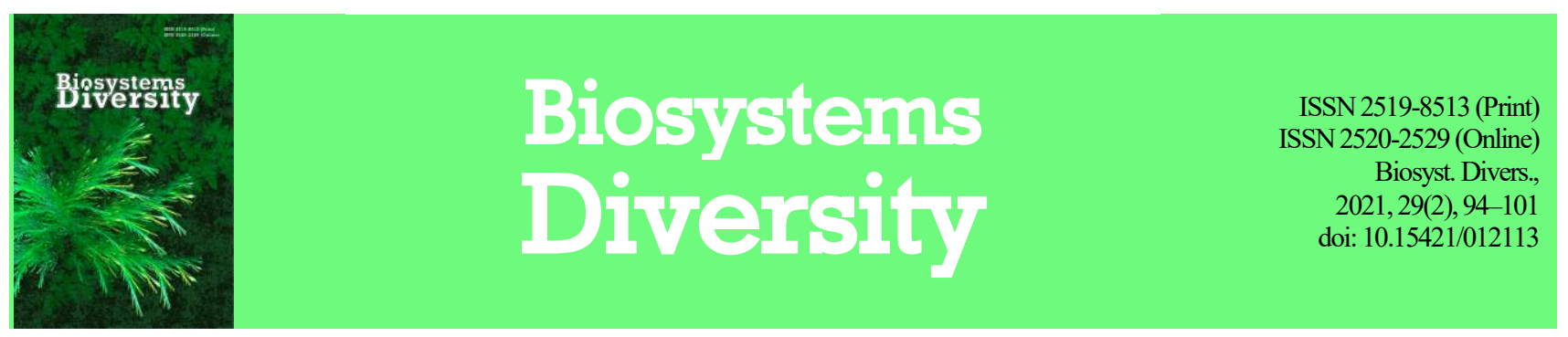

\title{
Ecological assemblages of corticulous myxomycetes in forest communities of the North-East Ukraine
}

\author{
A. V. Kochergina, T. Y. Markina \\ H. S. Skovoroda Kharkiv National Pedagogical University, Kharkiv, Ukraine
}

Article info
Received 08.01 .2021
Received in revised form
10.02 .2021
Accepted 11.02 .2021

H. S. Skovoroda Kharkiv National Pedagogical University, Valentynivska st., 2 Kharkiv, 61168, Ukraine. Tel.: + 38-057-267-69-92. E-mail: stacyscreations86@gmail.com

Kochergina, A. V., \& Markina, T. Y. (2021). Ecological assemblages of corticulous myxomycetes in forest communities of the NorthEast Ukraine. Biosystems Diversity, 29(2), 94-101. doi:10.15421/012113

Corticulous myxomycetes remain one of the least surveyed ecological groups of terrestrial protists. These organisms develop on the bark of trees, mostly feeding on bacteria and microalgae. Their microscopic size and fast developmental cycle (3-5 days) complicate the study of these organisms, and therefore data their on ecological relationships and patterns of biodiversity corticulous myxomycetes remain controversial. On the territory of the southwest spurs of the Central Russian Upland (Northeast Ukraine), no special studies on these organisms have been conducted. During 2017-2020, in nine forest sites located in this territory, we collected samples of bark of 16 species of tree plants, on which sporulating myxomycetes were then identified using the moist chamber technique in laboratory conditions. A total of 434 moist chambers was prepared, and 267 (61.5\%) of which were found to contain myxomycete fruiting bodies. In total, we made 535 observations, finding 20,211 sporocarps. As a result, in the surveyed territory, we found 38 species of corticulous myxomycetes, belonging to 18 genera, 10 families, 7 orders, and 2 subclasses of Myxomycetes. Among the species of corticulous myxomycetes, the most abundant were Echinostelium minutum, Arcyria pomiformis, Macbrideola cornea, Perichaena chrysosperma, Licea kleistobolus, Paradiacheopsis fimbriata, Cribraria violacea, Enerthenema papillatum, A. cinerea, and L. operculata. The greatest species richness in the examined biota was observed for genera Comatricha, Licea, Paradiacheopsis and Perichaena, families Amaurochaetaceae and Trichiaceae, orders Stemonitidales, Trichiales and Physarales. By species diversity, dark-spored myxomycetes (Collumellomycetidae) somewhat exceeded bright-spored myxomycetes (Lucisporomycetidae). Badhamia versicolor, Didymium dubium, D. sturgisii, Macbrideola decapillata, and Perichaena luteola are new species for the surveyed area. Four species of myxomycetes were collected in Ukraine for the first time: Hemitrichia pardina, Licea floriformis, L. pygmea, and Macbrideola argentea. Quantitative and qualitative structure of myxomycete consortia developing on different species of substrate-forming plants demonstrated significant differences. The highest level of similarity was demonstrated by Fraximus excelsior and Acer platanoides, and a relatively strong relationship was seen between Pinus sylvestris and Tilia cordata. The central cluster comprised F. excelsior, A. platanoides and P. sylvestris. By the sum of values of BrayCurtis coefficient, Quercus robur appeared to be most distinctive plant species by quantitative composition of myxomycete consortia. $F$. excelsior and $T$. cordata are the most favourable for the development of corticulous myxomycetes. In all the analyzed consortia, the dominant species belonged to the Stemonitidales and Trichiales orders, while the remaining orders were represented by notably fewer species. Relative species richness of Stemonitidales was the highest in consortia of $P$. sylvestris, the contribution of Liceales was the greatest in A. platanoides and P. sylvestris, the percentage of Echinosteliales and Physarales was the highest on $F$. excelsior, the share of Cribrariales was especially large on $A$. platanoides. Trichiales were represented on all the analyzed substrates to almost the same extent. Representatives of Cribrariales and Physarales were completely absent on P. sylvestris, the species of Clastodermatales - on all species of plants, except Q. robur. Prevalence of bright-spored myxomycetes was determined for consortia of Acer platanoides, the dominance of darkspored myxomycetes - for F. excelsior, P. sylvestris and Q. robur. The obtained data indicate the presence of stable complexes of corticulous myxomycetes, associated with different species of trees in the forest ecosystems of Northeast Ukraine. This encourages further study of the structure of myxomycete consortia with tree species that were not included in this study and determining the influence of physical-chemical properties of the bark of different plant species on the discovered peculiarities of myxomycete communities.

Keywords: consortive connections; epiphytic community; Eumycetozoa; moist chamber cultures; Myxogastrea; terrestrial protists; bark of living trees.

\section{Introduction}

Myxomycetes (Myxomycetes, =Myxogastrea) are terrestrial eukaryotic amoebae that are able to develop complex spore-forming structures. The life cycle of these organisms includes stages of single-nucleus amoebae cells (myxamoebae), multi-nuclear amoeboids (plasmoids) and fruiting bodies (sporocarps), in which the spore mass is covered by noncellular membranous coating (Clark \& Haskins, 2013; Stephenson \& Schnittler, 2017). The identification of myxomycetes is based on investigation of spores and non-cellular elements of their fruiting bodies (Leontyev \& Fefelov, 2012; Leontyev et al., 2014). According to contemporary views, myxomycetes belong to the Amoebozoa supergroup (Kang et al., 2017; Leontyev \& Schnittler, 2017) that also contains most of the lobose amoebae and some heterotrophic flagellates (Adl et al., 2019). The num- ber of described species of myxomycetes exceeds 1,100; in Ukraine, over 300 species of these organisms have been found (Leontyev et al., 2020). Distribution and ecological significance of myxomycetes is hard to overestimate: they account for $50 \%$ of biomass of soil amoebae and are essential regulators of the number of bacteria, algae and heterotrophic protists in terrestrial ecosystems (Urich et al., 2008; Leontyev et al., 2020).

In ecosystems, myxomycetes occupy the niche of microconsumers (Stephenson et al., 2016). The dependence of myxomycetes on the composition of communities of microorganisms that they consume restricts the abundance of myxomycete species and leads to development of specific complexes of these organisms, associated with a certain substrate, type of landscape, natural-climatic zone (Stephenson et al., 2008; Rollins \& Stephenson, 2011). Despite their distribution by spores, myxomycetes are not cosmopolites (Aguilar et al., 2014). The effect of substrate, in 
which the myxomycetes undergo most of the stages of their life cycle, is manifested in the distinct division of these organisms into several ecological groups, the main of which are xylophilous, corticulous, litter and nivicolous myxomycetes (Takahashi \& Harakon, 2012; Fiore-Donno et al., 2016).

One of the least studied ecological groups of Myxogastrea, and terrestrial protists in general, is the corticulous myxomycete group, which undergo all the stages of the life cycle on tree bark (Mitchell, 2004; Schnittler et al., 2016). The representatives of this group have been recorded on all continents and in all climate zones, including those with no forest vegetation, because of their abilities to develop on the caudexes of semi-shrubs and shrubs in tundra, steppes and deserts (Novozhilov et al., 2006, 2017a). Despite the fact that some species of corticulous myxomycetes have a broad distribution range and high density, the group in general is considered as more specialized than other ecological groups of myxomycetes (Everhart et al., 2009). Texture of the bark, hygroscopicity, $\mathrm{pH}$, the age of the tree and epiphyte load on its trunk have a significant effect on the species composition of corticulous myxomycetes. Similar peculiarities of substrate-forming plants are less important to litter, xylophilous and nivicolous species (Everhart et al., 2008; Schnittler, 2016).

The microscopic sizes and fast rates of the development cycle (35 days) make corticulous myxomycetes difficult to study. Therefore, the data on ecological relationships and patterns of biodiversity of these organisms remain contradictory (Rojas \& Stephenson, 2017). In particular, a significant problem is determining the qualitative and quantitative stricture of myxomycete communities in different biogeographic zones and on different species of substrate-forming plants (Schnittler et al., 2016). This is totally relevant for biota of corticulous myxomycetes of Ukraine, where specialized studies of corticulous myxomycetes have not been conducted so far. Some representatives of the group are reported for the Polesia (Leontyev et al., 2012), the mountain regions of the Crimea (Romanenko, 2002; Leontyev et al., 2011) and the Forest-Steppe zone of Ukraine (Leontyev, 2006b; Prylutskyi et al., 2017), but no general analysis of ecological peculiarities of corticulous myxomycetes has been performed so far for any of the landscape-climatic complexes of Ukraine.

The southwest spurs of the Central Russian Upland are a physicalgeographic area that comprises northeast part of the forest and foreststeppe belts of Ukraine. According to the botanical-geographic zoning, this territory belongs to district XIX of the Central Russian Sub-Province of the East European broad-leaved province and districts XXVIII-XXX of the Central Russian Forest-Steppe Sub-Province of the East European Forest-Steppe Province (Barbarych, 1977), and according to the zoning adopted in the studies of myxomycetes, the forest part of the territory corresponds to the Central Russian forests, and the forest-steppe part - to the Kharkiv Forest-Steppe (Heluta, 1989). Forest vegetation in this territory is mostly represented by oak, maple-lime-pine, oak-pine, pine, aspen and floodplain forests of various compositions. The main forest-forming trees there are Acer platanoides L., Tilia cordata Mill., Fraxinus excelsior L., Pinus sylvestris L. and Quercus robur L. (Barbarych, 1977; Heluta, 1989). Taking into account that quantitative and qualitative compositions of corticulous myxomycetes depend directly on the substrate-forming plants, the diversity of the vegetation in the territory of northeast of Ukraine allows one to expect broad diversity of these organisms (Schnittler et al., 2006; Vlasenko et al., 2020). To test this hypothesis, we performed studies on biodiversity and ecological peculiarities of myxomycetes of the northeast of Ukraine.

\section{Materials and methods}

We carried out the survey in the period 2017-2021 in nine forest territories, including six nature reserves and three forestries with no protection status (Table 1). In total, we collected 358 samples of the bark of 16 tree species (Acer campestre L., A. platanoides L., Betula pendula L., B. pubescens Ehrh., Crataegus sp., Fraxinus excelsior L., Gleditsia triacanthos L., Malus sylvestris L., Pinus sylvestris L., Prunus armeniaca L., P. domestica L., Populus tremula L., Quercus robur L., Robinia pseudoacacia L., Tilia cordata L., Ulmus sp.). The myxomycete fructifications were obtained using the moist chamber technique, which involves keeping the bark samples on moist filter paper in Petri dishes (Goad \& Stephenson, 2013; Schnittler et al., 2015). Incubation in humid conditions leads to germination of the spores of myxomycetes and the following development of their fruiting bodies. The bark was taken from trunks of over $20 \mathrm{~cm}$ diameter at the height of $1.5 \mathrm{~m}$ above the ground, around the whole perimeter of the trunk. We cut pieces of the outer dead layer of bark into sections of several square centimeters and put them into individual paper bags. The bark fragments were placed in the moist chambers so that the surface of Petri dishes is overlaid by one layer of the bark. The chambers were inspected on days 6-7, 10-13 and 18-20. In total, 434 moist chambers were used, $267(61.5 \%)$ of which myxomycete fruiting bodies were observed.

Table 1

Таблицы без названия недопустимы

\begin{tabular}{|c|c|c|c|}
\hline $\begin{array}{l}\text { Locality } \\
\text { abbreviation }\end{array}$ & Name of the locality & $\begin{array}{l}\text { Point of } \\
\text { sampling }\end{array}$ & Coordinates \\
\hline VB & $\begin{array}{l}\text { Vilkhova Balka Regional Land- } \\
\text { scape Park (Kharkiv Oblast) }\end{array}$ & 1 & $50.1774^{\circ} \mathrm{N}, 36.2731^{\circ} \mathrm{E}$ \\
\hline $\mathrm{HF}$ & $\begin{array}{l}\text { Homilsha Forests National Nature } \\
\text { Park (Kharkiv Oblast) }\end{array}$ & $\begin{array}{l}2 \\
3 \\
4 \\
5 \\
6 \\
7 \\
8 \\
9 \\
10 \\
11 \\
12 \\
13 \\
14 \\
15 \\
16 \\
17 \\
18 \\
19 \\
20 \\
21 \\
22 \\
23 \\
24 \\
25 \\
26 \\
27 \\
28 \\
29 \\
30 \\
31 \\
32 \\
33 \\
34 \\
35 \\
36 \\
37 \\
38 \\
39 \\
40 \\
41 \\
42 \\
43 \\
44 \\
45 \\
46 \\
47 \\
48 \\
49\end{array}$ & $\begin{array}{l}49.6236^{\circ} \mathrm{N}, 36.3225^{\circ} \mathrm{E} \\
49.6230^{\circ} \mathrm{N}, 36.3228^{\circ} \mathrm{E} \\
49.6229^{\circ} \mathrm{N}, 36.3229^{\circ} \mathrm{E} \\
49.6230^{\circ} \mathrm{N}, 36.3232^{\circ} \mathrm{E} \\
49.6230^{\circ} \mathrm{N}, 36.3232^{\circ} \mathrm{E} \\
49.6229^{\circ} \mathrm{N}, 36.3235^{\circ} \mathrm{E} \\
49.6229^{\circ} \mathrm{N}, 36.3224^{\circ} \mathrm{E} \\
49.6227^{\circ} \mathrm{N}, 36.3222^{\circ} \mathrm{E} \\
49.6224^{\circ} \mathrm{N}, 36.3222^{\circ} \mathrm{E} \\
49.6222^{\circ} \mathrm{N}, 36.3223^{\circ} \mathrm{E} \\
49.6214^{\circ} \mathrm{N}, 36.3202^{\circ} \mathrm{E} \\
49.61977^{\circ}, 36.3152^{\circ} \mathrm{E} \\
49.6193^{\circ} \mathrm{N}, 36.3153^{\circ} \mathrm{E} \\
49.6188^{\circ} \mathrm{N}, 3633154^{\circ} \mathrm{E} \\
49.6188^{\circ} \mathrm{N}, 3633154^{\circ} \mathrm{E} \\
49.6188^{\circ} \mathrm{N}, 36.3154^{\circ} \mathrm{E} \\
49.6188^{\circ} \mathrm{N}, 36.3154^{\circ} \mathrm{E} \\
49.6186^{\circ} \mathrm{N}, 36.3152^{\circ} \mathrm{E} \\
49.6186^{\circ} \mathrm{N}, 36.3152^{\circ} \mathrm{E} \\
49.5805^{\circ} \mathrm{N}, 36.3490^{\circ} \mathrm{E} \\
49.5810^{\circ} \mathrm{N}, 36.3498^{\circ} \mathrm{E} \\
49.5810^{\circ} \mathrm{N}, 36.3498^{\circ} \mathrm{E} \\
49.5807^{\circ} \mathrm{N}, 36.3497^{\circ} \mathrm{E} \\
49.5816^{\circ} \mathrm{N}, 36.3514^{\circ} \mathrm{E} \\
49.5822^{\circ} \mathrm{N}, 36.3521^{\circ} \mathrm{E} \\
49.5828^{\circ} \mathrm{N}, 36.3570^{\circ} \mathrm{E} \\
49.5840^{\circ} \mathrm{N}, 36.3619^{\circ} \mathrm{E} \\
49.6175^{\circ} \mathrm{N}, 3636362^{\circ} \mathrm{E} \\
49.6169^{\circ} \mathrm{N}, 363601^{\circ} \mathrm{E} \\
49.6163^{\circ} \mathrm{N}, 36.3602^{\circ} \mathrm{E} \\
49.6156^{\circ} \mathrm{N}, 36.3601^{\circ} \mathrm{E} \\
49.6148^{\circ} \mathrm{N}, 36.3604^{\circ} \mathrm{E} \\
49.6141^{\circ} \mathrm{N}, 36.3602^{\circ} \mathrm{E} \\
49.6160^{\circ} \mathrm{N}, 36.3142^{\circ} \mathrm{E} \\
49.6159^{\circ} \mathrm{N}, 36.3167^{\circ} \mathrm{E} \\
49.6159^{\circ} \mathrm{N}, 36.3170^{\circ} \mathrm{E} \\
49.6159^{\circ} \mathrm{N}, 36.3172^{\circ} \mathrm{E} \\
49.6161^{\circ} \mathrm{N}, 36.3171^{\circ} \mathrm{E} \\
49.6160^{\circ} \mathrm{N}, 36.3172^{\circ} \mathrm{E} \\
49.6112^{\circ} \mathrm{N}, 36.3241^{\circ} \mathrm{E} \\
49.6239^{\circ} \mathrm{N}, 36.3199^{\circ} \mathrm{E} \\
49.6230^{\circ} \mathrm{N}, 3633223^{\circ} \mathrm{E} \\
49.6224^{\circ}, 36.3219^{\circ} \mathrm{E} \\
49.6224^{\circ}, 36363219^{\circ} \mathrm{E} \\
49.6226^{\circ} \mathrm{N}, 36.3219^{\circ} \mathrm{E} \\
49.6226^{\circ} \mathrm{N}, 36.3221^{\circ} \mathrm{E} \\
49.6222^{\circ} \mathrm{N}, 36.3224^{\circ} \mathrm{E} \\
49.6220^{\circ} \mathrm{N}, 36.3227^{\circ} \mathrm{E}\end{array}$ \\
\hline $\mathrm{DF}$ & $\begin{array}{l}\text { Derhachivske Forestry (Kharkiv } \\
\text { Oblast) }\end{array}$ & 50 & $50.1655^{\circ} \mathrm{N}, 36.3209^{\circ} \mathrm{E}$ \\
\hline $\mathrm{ZF}$ & $\begin{array}{l}\text { Zolochivske Forestry (Kharkiv } \\
\text { Oblast) }\end{array}$ & 51 & $50.2502^{\circ} \mathrm{N}, 35.9340^{\circ} \mathrm{E}$ \\
\hline $\mathrm{KD}$ & $\begin{array}{l}\text { Kochetotska Lisova Dacha Land- } \\
\text { scape Reserve (Kharkiv Oblast) }\end{array}$ & $\begin{array}{l}52 \\
53 \\
54 \\
55 \\
56 \\
57 \\
58 \\
59\end{array}$ & $\begin{array}{l}49.9290^{\circ} \mathrm{N}, 36.7475^{\circ} \mathrm{E} \\
49.9292^{\circ} \mathrm{N}, 36.7471^{\circ} \mathrm{E} \\
49.9293^{\circ} \mathrm{N}, 36.7479^{\circ} \mathrm{E} \\
49.9294^{\circ} \mathrm{N}, 36.7485^{\circ} \mathrm{E} \\
49.9294^{\circ} \mathrm{N}, 36.7485^{\circ} \mathrm{E} \\
49.9294^{\circ} \mathrm{N}, 36.7484^{\circ} \mathrm{E} \\
49.9296^{\circ} \mathrm{N}, 36.7485^{\circ} \mathrm{E} \\
49.9291^{\circ} \mathrm{N}, 36.7480^{\circ} \mathrm{E}\end{array}$ \\
\hline MF & Makivske Forestry (Sumy Oblast) & $\begin{array}{l}60 \\
61\end{array}$ & $\begin{array}{l}50.5683^{\circ} \mathrm{N}, 34.9882^{\circ} \mathrm{E} \\
50.5680^{\circ} \mathrm{N}, 34.9883^{\circ} \mathrm{E}\end{array}$ \\
\hline
\end{tabular}




\begin{tabular}{|c|c|c|c|}
\hline \multirow[t]{24}{*}{$\begin{array}{c}\text { Locality } \\
\text { abbreviation }\end{array}$} & Name of the locality & $\begin{array}{c}\text { Point of } \\
\text { sampling }\end{array}$ & Coordinates \\
\hline & & 62 & $50.5680^{\circ} \mathrm{N}, 34.9884^{\circ} \mathrm{E}$ \\
\hline & & 63 & $50.5681^{\circ} \mathrm{N}, 34.9894^{\circ} \mathrm{E}$ \\
\hline & & 64 & $50.5680^{\circ} \mathrm{N}, 34.9898^{\circ} \mathrm{E}$ \\
\hline & & 65 & $50.5678^{\circ} \mathrm{N}, 34.9902^{\circ} \mathrm{E}$ \\
\hline & & 66 & $50.5678^{\circ} \mathrm{N}, 34.9902^{\circ} \mathrm{E}$ \\
\hline & & 67 & $50.5678^{\circ} \mathrm{N}, 34.9902^{\circ} \mathrm{E}$ \\
\hline & & 68 & $50.5671^{\circ} \mathrm{N}, 34.9911^{\circ} \mathrm{E}$ \\
\hline & & 69 & $50.5668^{\circ} \mathrm{N}, 34.9913^{\circ} \mathrm{E}$ \\
\hline & & 70 & $50.5661^{\circ} \mathrm{N}, 34.9912^{\circ} \mathrm{E}$ \\
\hline & & 71 & $50.5661^{\circ} \mathrm{N}, 34.9912^{\circ} \mathrm{E}$ \\
\hline & & 72 & $50.5659^{\circ} \mathrm{N}, 34.9928^{\circ} \mathrm{E}$ \\
\hline & & 73 & $50.5659^{\circ} \mathrm{N}, 34.9929^{\circ} \mathrm{E}$ \\
\hline & & 74 & $50.5654^{\circ} \mathrm{N}, 34.9931^{\circ} \mathrm{E}$ \\
\hline & & 75 & $50.5654^{\circ} \mathrm{N}, 34.9931^{\circ} \mathrm{E}$ \\
\hline & & 76 & $50.5654^{\circ} \mathrm{N}, 34.9931^{\circ} \mathrm{E}$ \\
\hline & & 77 & $50.5651^{\circ} \mathrm{N}, 34.9931^{\circ} \mathrm{E}$ \\
\hline & & 78 & $50.5648^{\circ} \mathrm{N}, 34.9932^{\circ} \mathrm{E}$ \\
\hline & & 79 & $50.5648^{\circ} \mathrm{N}, 34.9932^{\circ} \mathrm{E}$ \\
\hline & & 80 & $50.5631^{\circ} \mathrm{N}, 35.0463^{\circ} \mathrm{E}$ \\
\hline & & 81 & $50.5631^{\circ} \mathrm{N}, 35.0450^{\circ} \mathrm{E}$ \\
\hline & & 82 & $50.5201^{\circ} \mathrm{N}, 35.0331^{\circ} \mathrm{E}$ \\
\hline & & 83 & $50.5202^{\circ} \mathrm{N}, 35.0330^{\circ} \mathrm{E}$ \\
\hline & & 84 & $50.4954^{\circ} \mathrm{N}, 34.9966^{\circ} \mathrm{E}$ \\
\hline \multirow[t]{11}{*}{ SE } & Seimsky Regional Landscape Park & 85 & $51.3933^{\circ} \mathrm{N}, 33.5606^{\circ} \mathrm{E}$ \\
\hline & (Sumy Oblast) & 86 & $51.3784^{\circ} \mathrm{N}, 33.4789^{\circ} \mathrm{E}$ \\
\hline & & 87 & $51.3917^{\circ} \mathrm{N}, 33.4795^{\circ} \mathrm{E}$ \\
\hline & & 88 & $51.3888^{\circ} \mathrm{N}, 33.4757^{\circ} \mathrm{E}$ \\
\hline & & 89 & $51.3871^{\circ} \mathrm{N}, 33.4765^{\circ} \mathrm{E}$ \\
\hline & & 90 & $51.3854^{\circ} \mathrm{N}, 33.4769^{\circ} \mathrm{E}$ \\
\hline & & 91 & $51.3845^{\circ} \mathrm{N}, 33.4764^{\circ} \mathrm{E}$ \\
\hline & & 92 & $51.3845^{\circ} \mathrm{N}, 33.4769^{\circ} \mathrm{E}$ \\
\hline & & 93 & $51.3843^{\circ} \mathrm{N}, 33.4770^{\circ} \mathrm{E}$ \\
\hline & & 94 & $51.3839^{\circ} \mathrm{N}, 33.4762^{\circ} \mathrm{E}$ \\
\hline & & 95 & $51.3835^{\circ} \mathrm{N}, 33.4762^{\circ} \mathrm{E}$ \\
\hline \multirow[t]{2}{*}{ SL } & Slobozhansky National Nature & 96 & $50.1055^{\circ} \mathrm{N}, 35.2811^{\circ} \mathrm{E}$ \\
\hline & Park (Kharkiv Oblast) & & \\
\hline \multirow[t]{9}{*}{ SP } & Sokilnyky-Pomirky Regional & 97 & $50.0413^{\circ} \mathrm{N}, 36.2597^{\circ} \mathrm{E}$ \\
\hline & Landscape Park (Kharkiv Oblast) & 98 & $50.0414^{\circ} \mathrm{N}, 36.2632^{\circ} \mathrm{E}$ \\
\hline & & 99 & $50.0414^{\circ} \mathrm{N}, 36.2638^{\circ} \mathrm{E}$ \\
\hline & & 100 & $50.0412^{\circ} \mathrm{N}, 36.2645^{\circ} \mathrm{E}$ \\
\hline & & 101 & $50.0413^{\circ} \mathrm{N}, 36.2651^{\circ} \mathrm{E}$ \\
\hline & & 102 & $50.0412^{\circ} \mathrm{N}, 36.2657^{\circ} \mathrm{E}$ \\
\hline & & 103 & $50.0413^{\circ} \mathrm{N}, 36.2664^{\circ} \mathrm{E}$ \\
\hline & & 104 & $50.0411^{\circ} \mathrm{N}, 36.2668^{\circ} \mathrm{E}$ \\
\hline & & 105 & $50.0535^{\circ} \mathrm{N}, 36.2690^{\circ} \mathrm{E}$ \\
\hline
\end{tabular}

According to the generally accepted technique (Spiegel et al., 2004; Rojas \& Stephenson, 2017), the abundance of myxomycetes found in moist chambers was determined according to two parameters: number of observations and number of sporocarps. The observation was considered as the presence of a certain species in one moist chamber. A separate fruiting body of a myxomycete or dense, morphologically indivisible group of fruiting bodies was calculated as one sporocarp. The significant variation in the numbers of sporocarps, including 10-20-fold differences among some species, complicates the visualization of this parameter. Therefore, to compare the species by number of sporocarps, we used binary logarithm of this value. Throughout the study, we made 535 observations of corticulous myxomycetes and found 20,211 sporocarps of these organisms. The species were identified according to the specialized sources (Mitchell, 2004; Poulain et al., 2011). Classification of myxomycetes is given according to Leontyev et al. (2019). The material of the study is stored in the mycological section of the Scientific Herbarium of H. S. Skovoroda Kharkiv National Pedagogical University (CWP).

As a parameter of diversity of myxomycetes, we used the Margalef index (Gotelli \& Chao, 2013). Qualitative and quantitative composition of myxomycete consortia were compared using Bray-Curtis index (Ricotta \& Podani, 2017). Visualization of the similarities between the myxomycete consortia was made using the similarity graph, developed according to Godsil \& Royle (2001).

\section{Results}

In the territory of southwest spurs of the Central Russian Upland, we found 38 species of corticulous myxomycetes, belonging to 18 genera, 10 families, 7 orders and 2 subclasses of Myxomycetes class. Below we provide a systematic list of these species. Abbreviations for the localities are given in parentheses (Table 1).

Class Myxomycetes G. Winter

Subclass Lucisporomycetidae Leontyev, Schnittler, S. L. Stephenson,

Novozhilov \& Shchepin

Cribrariales T. Macbr.

Cribrariaceae Corda

Cribraria violacea $\mathrm{Rex}(\mathrm{HF}, \mathrm{DF}, \mathrm{KD}, \mathrm{MF}, \mathrm{SP})$

Liceales E. Jahn

Liceaceae Chevall.

Licea floriformis T. N. Lakh. \& R. K. Chopra (SP)

L. kleistobolus G. W. Martin (HF, MF, SE, SP)

L. operculata (Wingate) G. W. Martin (HF, SP)

L. pygmea (Meyl.) Ing (HF)

Trichiales T. Macbr.

Dianemataceae T. Macbr.

Calomyxa metallica (Berk.) Nieuwl. (HF, SP)

Trichiaceae Chevall.

Arcyria cinerea (Bull.) Pers. (HF, MF, SL, SP)

A. minuta Buchet (HF, DF)

A. pomiformis (Leers) Rostaf. (HF, MF, SE, SL, SP)

Hemitrichia pardina (Minakata) Ing (HF)

H. serpula (Scop.) Rostaf. ex Lister (SP)

Perichaena chrysosperma (Curr.) Lister (VB, HF, MF, SE, SP)

P. corticalis (Batsch) Rostaf. (SL)

P. luteola (Kowalski) Gilert (MF)

P. vermicularis (Schwein.) Rostaf. (HF, DF, KD, MF)

Trichia contorta (Ditmar) Rostaf. (HF)

Subclass Columellomycetidae Leontyev, Schnittler, S. L. Stephenson,

Novozhilov \& Shchepin

Echinosteliales G. W. Martin

Echinosteliaceae Rostaf. ex Cooke

Echinostelium elachiston Alexop. (KD)

E. minutum de Bary (HF, MF, SE, SP)

Clastodermatales Leontyev, Schnittler, S. L. Stephenson, Novozhilov

\& Shchepin

Clastodermataceae Alexop. \& T. E. Brooks

Clastoderma debaryanum A. Blytt (SP)

Stemonitidales T. Macbr.

Stemonitidaceae $\mathrm{Fr}$

Macbrideola argentea Nann.-Bremek. \& Y. Yamam. (HF)

M. cornea (G. Lister \& Cran) Alexop. (VB, HF, KD, MF, SE)

M. decapillata H. C. Gilbert (HF)

Stemonitis pallida Wingate (SE)

Amaurochaetaceae Rostaf. ex Cooke

Comatricha elegans (Racib.) G. Lister (HF, SL)

C. ellae Härk. (HF, SE, SP)

C. laxa Rostaf. (HF, SL)

C. nigra (Pers. ex J. F. Gmel.) J. Schröt. (SP)

Stemonitopsis amoena (Nann.-Bremek.) Nann.-Bremek. (SP)

Enerthenema papillatum (Pers.) Rostaf. (HF, MF, SE, SL, SP)

Paradiacheopsis acanthodes (Alexop.) Nann.-Bremek. (HF)

P. fimbriata (G. Lister \& Cran) Hertel ex Nann.-Bremek. (HF, SE)

P. rigida (Brândza) Nann.-Bremek. (HF)

Physarales T. Macbr.

Didymiaceae Rostaf. ex Cooke

Didymium bahiense Gottsb. (ZF)

D. dubium Rostaf. (HF)

D. sturgisii Hagelst. (HF)

Physaraceae Chevall.

Badhamia versicolor Lister (HF)

Physarum compressum Alb. \& Schwein. (HF)

Ph. decipiens M. A. Curtis (HF)

The discovered species differ significantly by their distribution in the surveyed area (Fig. 1). According to the number of observations, leading positions belong to $E$. minutum and A. pomiformis, and somewhat lower abundance was seen for $M$. cornea, P. chrysosperma, L. kleistobolus, $P$. fimbriata and $C$. violacea. Over ten observations were also made for E. papillatum, P. vermicularis, A. cinerea and L. operculata and C. ellae. 
Less than ten observations were made for 26 (68.4\%) species. Abundance of sporulation did not always correlate with the distribution of the species. According to the number of sporocarps found, E. minutum significantly exceeded other species (12,180 sporocarps; $60.3 \%$ of the total number of sporocarps of myxomycetes), and even the most abundant species were much more inferior according to this parameter: A. pomiformis $(2,144$; $10.6 \%)$, L. kleistobolus $(1,879 ; 9.3 \%)$, M. cornea $(1,202 ; 5.9 \%)$. Over 100 sporocarps were also recorded in $P$. chrysosperma, E. papillatum, L. operculata, $P$. fimbriata, $C$. violacea, $P$. vermicularis, $A$. cinerea and E. elachiston, and the latter species had a much higher number of sporocarps than species with a comparable numbers of observations. Taxonomic structure of biota of corticulous myxomycetes of the northeast of
Ukraine was characterized by the following traits. According to the number of species, the leading positions belonged to genera Comatricha, $\mathrm{Li}$ cea, Paradiacheopsis and Perichaena, families Amaurochaetaceae and Trichiaceae, and orders Stemonitidales, Trichiales and Physarales (Fig. 2). Dark-spored myxomycetes (Columellomycetidae) somewhat exceeded the bright-spored myxomycetes (Lucisporomycetidae) by species diversity: 23 species (59.0\% of the total number) and $16(41.0 \%)$, respectively. This tendency increases according to the number of found sporocarps: dark-spored myxomycetes were represented by 14,949 sporocarps (74.3\% of their total number), and bright-spored myxomycetes by 5,263 sporocarps $(26.2 \%)$. The proportions of the surveyed biota equaled 2.2 : $1.8: 1.4: 3.5: 2.0$.

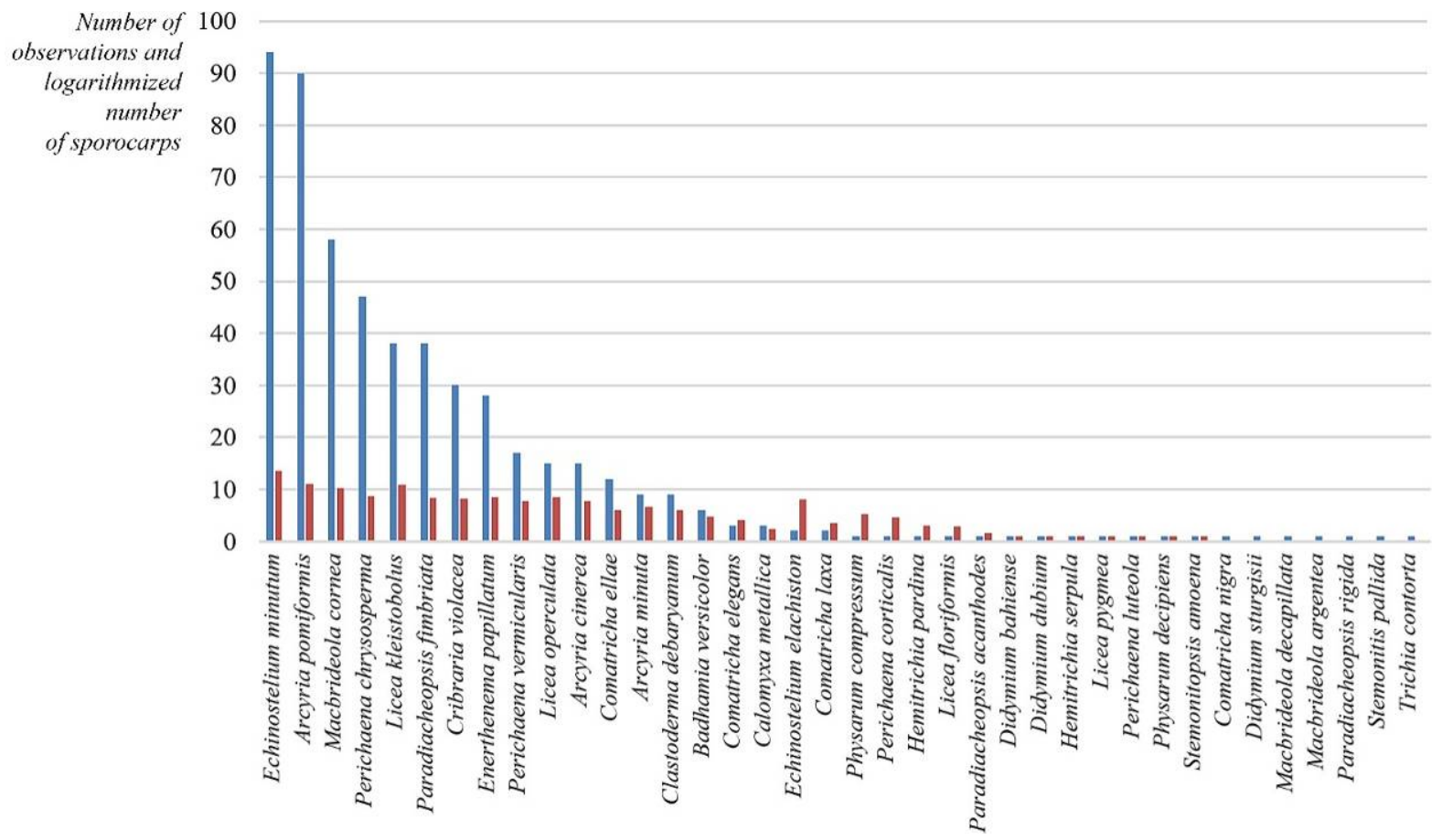

Fig. 1. Distribution of species of corticulous myxomycetes in northeast of Ukraine according to the number of observations and sporocarps: blue columns - number of observations, i.e. findings of one species in one moist chamber $(n=535)$; red columns - binary logarithm of number of sporocarps $(n=20,211)$; logarithm of number of sporocarps was used for the visualization of this parameter because of broad range of its values (1-2 orders), which complicates the visual interpretation of the data
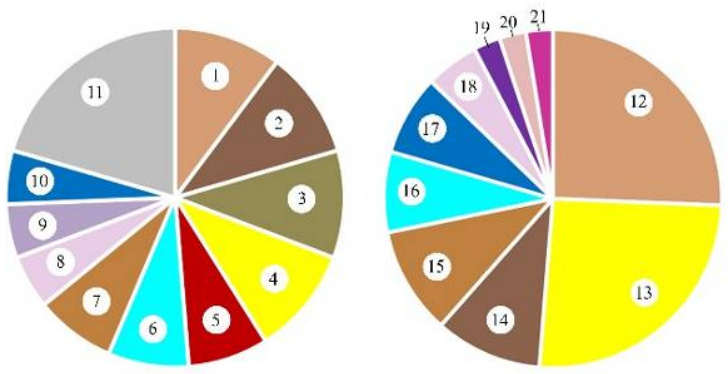

b

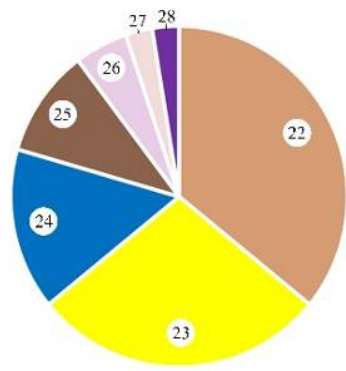

c
1. Comatricha

2. Licea

3. Paradiacheopsis

4. Perichaena

5. Arcyria

6. Didymium

7. Macbrideola

8. Echinostelium

9. Hemitrichia

10. Physarum

11. Rest of genera

12. Amaurochaetaceae

13. Trichiaceac

14. Liceaceae
15. Stemonitidaceae

16. Didymiaceae

17. Physaraceae

18. Echinosteliaceae

19. Clastodermatacea

20. Cribrariaceae

21. Dianemataceae

22. Stemonitidales

23. Trchiales

24. Physarales

25. Liceales

26. Echinosteliales

27. Clastodermatales

28. Cribrariales

Fig. 2. Proportions of supraspecific taxa of corticulous myxomycetes in northeast of Ukraine according to number of species:

$a$-spectrum of genera; $b$ - spectrum of families; $c$ - spectrum of orders; the leading taxa were Comatricha (4 species / 10.3\%), Licea (4 species / 10.3\%),

Paradiacheopsis (4 species / 10.3\%), Perichaena (4 species / 10.3\%), Arcyria (3 species / 7.7\%), Didymium (3 species / 7.7\%), Macbrideola

(3 species / 7.7\%), Echinostelium ( 2 species / 5.1\%), Hemitrichia ( 2 species / 5.1\%), Physarum (3 species / 5.1\%), Amaurochaetaceae

(10 species / 25.6\%), Trichiaceae (10 species / 25.6\%), Liceaceae (4 species / 10.3\%), Stemonitidaceae (4 species / 10.3\%), Didymiaceae

(3 species / 7.7\%), Physaraceae (3 species / 7.7\%), Echinosteliaceae (2 species / 5.1\%), Clastodermataceae (1 species / 2.6\%), Cribrariaceae

(1 species / 2.6\%), Dianemataceae (1 species / 2.6\%), Stemonitidales (14 species / 35.9\%), Trchiales (11 species / 28.2\%), Physarales (6 species / 15.4\%),

Liceales (4 species / 10.3\%), Echinosteliales (2 species / 5.1\%), Clastodermatales (1 species / 2.6\%) and Cribrariales (1 species / 2.6\%)

Among the 38 species found in the territory of Kharkiv ForestSteppe, nine (23.6\%) were new to this area: Badhamia versicolor, $D$. dubium, D. sturgisii, Hemitrichia pardina, Licea floriformis, L. pygmea, Macbrideola argentea, M. decapillata and Perichaena luteola. Two of them, M. decapillata and P. luteola, were recorded for the first time in the lowland part of Ukraine, and another four are new to Ukraine: H. pardina,
L.floriformis, L. pygmea, M. argentea. Among six species found in the territory of the Central Russian forests, all were discovered in this geobotanical region for the first time. All of them are common species with a wide distribution: Arcyria cinenrea, A. pomiformis, Comatricha elegans, C. laxa, Enerthenema papillatum, Perichaena corticalis. Below, we provide morphological descriptions of the species that were new to Ukraine. 
Hemitrichia pardina (Minakata) Ing, Myxomycetes Britain and Ireland 132 (1999). Sporocarps stipitate, scattered, up to $0.8 \mathrm{~mm}$ high, yellow, spotted. Hypothallus inconspicuous. The stalk short, up to $0.3 \mathrm{~mm}$ long, black. Peridium membranous, bears convex, dark-brown to black areolae. Capillitium is composed of long, poorly branched tubes $2-4 \mu \mathrm{m}$ in diameter, ornamented with spirals and short spines up to $1 \mu \mathrm{m}$ long. Spores in mass yellow, pale-green-yellow by transmitted light, 9-11 $\mu \mathrm{m}$ in diameter. Found in: HF, the Kozacha Mountain, on the bark of Tilia cordata, 21.10.2018 (date of collecting the bark), $49.5816^{\circ} \mathrm{N}, 36.3514^{\circ} \mathrm{E}$.

Licea floriformis T. N. Lakh. \& R. K. Chopra, in Lakhanpal, Nannenga-Bremekamp \& Chopra, Proc. Kon. Ned. Akad. Wetensch., C. 93(3):255 (1990). Sporocarps stipitate, up to $0.7 \mathrm{~mm}$ long. Stalk stout, cylindrical, thickened in the lower part, with longitudinal grooves, almost black, $0.25-0.45 \mathrm{~mm}$ long. Sporotheca globular or suboval, 0.25 $0.35 \mathrm{~mm}$ in diameter, dark-brown to almost black, indistinctly wrinkled, with no lid. Peridium coriaceous, relatively thin, with unclear concentric zones, dehiscence into irregular radial lobes. Spores in mass dark, pale yellow by transmitted light, smooth, 11-12 (14) $\mu \mathrm{m}$ in diameter. Found in: SP, in northeast part of the forest, on the bark of Gleditsia triacanthos, 28.10.2008 (date of collecting the bark), $50.0535^{\circ} \mathrm{N}, 36.2690^{\circ} \mathrm{E}$.

Licea pygmea (Meyl.) Ing, Trans. Brit. Mycol. Soc. 78(3):443 (1982). Sporocarps sessile, more or less isodiametrical, irregularly polygonal, $0.05-0.30 \mathrm{~mm}$ in diameter. Peridium splits along the folds, the margin of the pridial fragments bears one row of the small papillae. Spores dark-brown in mass, light-brown by transmitted light, $11-14 \mu \mathrm{m}$ in diameter. Found in: HF, Zadinetsky pine forest, on the bark of Pinus sylvestris, 21.10 .2018 (date when the bark was collected), $49.6156^{\circ} \mathrm{N}$,
36.3601 ${ }^{\circ}$ E. Macbrideola argentea Nann.-Bremek. \& Y. Yamam., Proc. Kon. Ned. Akad. Wetensch., C. 86(2):228 (1983). Sporocarps stalked, solitary, $0.5-1.0 \mathrm{~mm}$ high. Stalk straight, forming $75-80 \%$ of the total height of the sporocarp, thins toward the top, almost black, red-brown in the base; the lower part translucent by transmitted light, indistinctly longitudinally striped, hollow. Sporotheca spherical, $0.1 \mathrm{~mm}$ in diameter. Peridium does not disappear after maturation, membranous, translucent, slightly iridescent. Columella almost reaches half of the sporotheca, splits into two-three branches and merges with the capillitium. Capillitium dark brown, composed of thin, relatively flexible filaments, with innumerous anastomoses. Spores are dark-brown in mass, pale grey by transmitted light, verrucose, with small groups of darker and larger warts, 7.0-8.5 $\mu \mathrm{m}$ in diameter. Found in: HF, the Kozacha Mountain, on the bark of Tilia cordata, 21.10.2018 (date when the bark was collected), $49.5807^{\circ} \mathrm{N}$, $36.3497^{\circ} \mathrm{E}$

Quantitative and qualitative composition of myxomycete communities that develop on different species of substrate-forming plants demonstrate significant differences (Table 2); hereinafter the analysis involves only five species of plants on which over 1,000 sporocarps and over 5 species of myxomycetes were found. The highest number of myxomycete species was found on the bark of Quercus robur, Tilia cordata and Fraxinus excelsior. The indicated species dominated by sporocarp number as well. Species diversity of the consortia of corticulous myxomycetes, calculated using the Margalef index, was the highest for the communities of $T$. cordata, F. excelsior and $Q$. robur. According to the mean number of species per moist chamber, the leading positions belonged to $T$. cordata and $F$. excelsior.

\section{Table 2}

Density and species diversity of corticulous myxomycetes on prevailing species of substrate-forming plants

\begin{tabular}{|c|c|c|c|c|c|}
\hline \multirow[b]{2}{*}{ Species of plants } & \multicolumn{5}{|c|}{ Parameters } \\
\hline & $\begin{array}{l}\text { Number of species } \\
\text { of myxomycetes }\end{array}$ & $\begin{array}{l}\text { Number of sporocarps } \\
\text { of myxomycetes }\end{array}$ & Margalef index & $\begin{array}{l}\text { Percent of positive } \\
\text { moist chambers, } \%\end{array}$ & $\begin{array}{l}\text { Mean number of species } \\
\text { per moist chamber }\end{array}$ \\
\hline Acerplatanoides & 10 & 1274 & 1.26 & 72.4 & 0.11 \\
\hline Fraxinus excelsior & 15 & 2031 & 1.84 & 66.7 & 0.14 \\
\hline Pinus sylvestris & 11 & 1640 & 1.35 & 71.6 & 0.10 \\
\hline Quercus robur & 17 & 9124 & 1.75 & 91.8 & 0.09 \\
\hline Tilia cordata & 16 & 2322 & 1.94 & 74.5 & 0.15 \\
\hline
\end{tabular}

Quantitative and qualitative composition of myxomycetes on different species of substrate-forming plants varied widely. In particular, on the bark of $A$. campestre, the prevailing species were A. pomiformis and L. kleistobolus (each accounted for $21.4 \%$ of the total number of positive observations), on A. platanoides - M. cornea (20.6\%) and L. kleistobolus $(14.3 \%)$, on B. pendula - E. minutum $(80.0 \%)$, on Crataegus sp. A. pomiformis and $P$. chrysosperma (26.7\% each), on $F$. excelsior M. cornea $(41.7 \%)$ and C. violacea (18.1\%), on P. sylvestris - P. fimbriata $(46.2 \%)$, on $Q$. robur - A. pomiformis (32.0\%) and A. minuta (30.2\%), on T. cordata - A. pomiformis (17.7\%), A. minutum (16.5\%) and P. chrysosperma (12.7), on Ulmus sp. - P. chrysosperma (41.2\%).

The consortia were compared according to qualitative and quantitative composition using the Bray-Curtis coefficient (Fig.3).

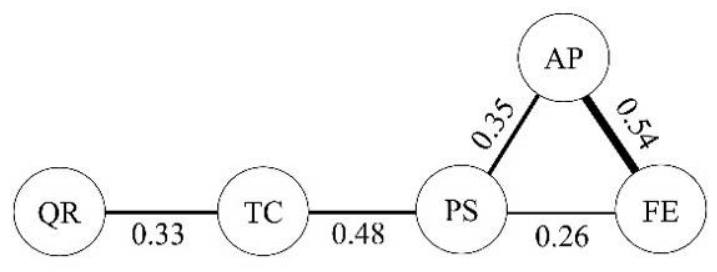

Fig. 3. Graph of similarity of substrate-forming plants according to species composition of the consortia of corticulous myxomycetes: the values of the Bray-Curtis coefficient that exceed the value of 0.20 are shown; the thickness of the lines is proportional to the value of the coefficient; AP - Acer platanoides, $\mathrm{FE}$ - Fraxinus excelsior,

PS - Pinus sylvestris, QR - Quercus robur, TC - Tilia cordata

The highest level of similarity was exhibited by $F$. excelsior and A.platanoides, relatively strong was also the relationship between P. sylvestris and T. cordata. The central cluster of the graph comprised
F. excelsior, A. platanoides and P. sylvestris. According to the sum of values of the Bray-Curtis coefficient, the consortium of myxomycete on Q. robur has the most specific composition of myxomycetes $(0.60)$.

Communities of corticulous myxomycetes on different substrate-forming plants differ by the number of species in different orders and subclasses (Fig. 4). We determined that in all analyzed substrates species of Stemonitidales and Trichiales were the most numerous, whereas Physarales, Liceales and Echinosteliales were represented by a noticeably lower number of species. The percent of Stemonitidales was the greatest in the consortia of $P$. sylvestris, share of Liceales - on A. platanoides and P. sylvestris, shares of Echinosteliales and Physarales - on F. excelsior, and the share of Cribrariales - on A. platanoides. Trichiales were represented in all analyzed substrates to almost the same degree. Representatives of Cribrariales and Physarales were completely absent on $P$. sylvestris, representatives of Clastodermatales - in all species of plants, except for Q. robur.

The ratio between the classes of myxomycetes according to the species diversity on the bark of different species of plants varies insignificantly. Prevalence of bright-spored myxomycetes was found in the consortia of A. platanoides, prevalence of dark-spored ones was observer on F. excelsior, P. sylvestris and $Q$. robur. On the bark of $T$. cordata, both taxonomic groups were represented by an equal number of species.

\section{Discussion}

The study we performed is a record for Ukraine for the amount of collected material (Romanenko, 2002; Leontyev, 2006a), thus allowing us to confirm the patterns earlier found in other regions of the world and detect some earlier undetermined peculiarities of the substrate ecology of myxomycetes. Similarly to the previous studies (Borg Dahl et al., 2019; Shchepin et al., 2019), abundance and diversity of corticulous myxomy- 
cetes were found to be the highest on the commonest species of substrateforming plants. However, we have shown that differences between the consortia in abundance of myxomycetes cannot be explained only by the number of collected samples. The ratio between the number of species and the number of positive moist chambers, which we calculated, revealed that leading positions according to both parameters belonged to T. cordata and $F$. excelsior, the species that were neither the commonest in the surveyed territory nor represented in our study by the highest number of

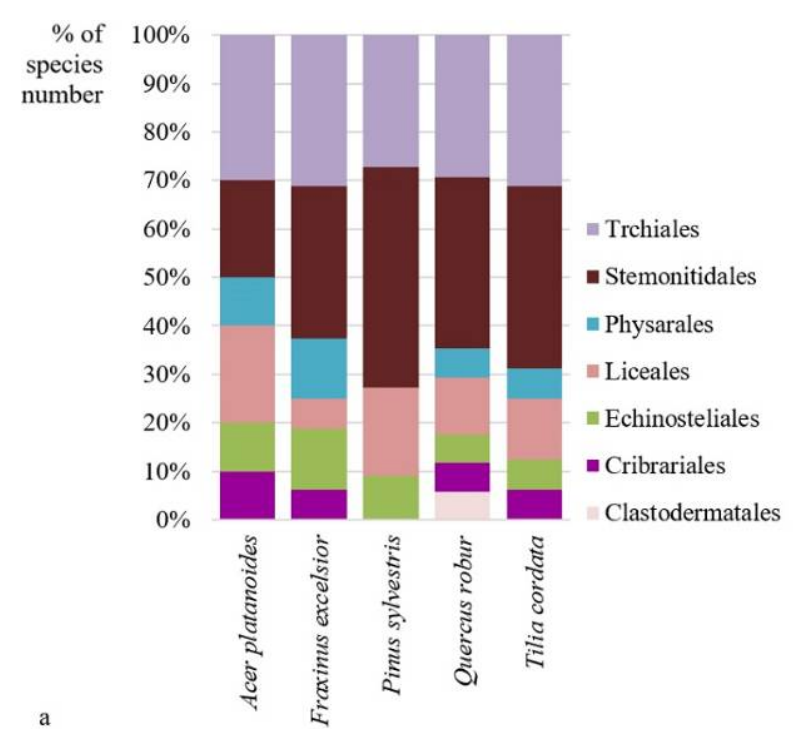

moist chambers (these were $Q$. robur and $P$. sylvestris in both cases). It has to be noted that $T$. cordata and $F$. excelsior also exhibited the highest values of the Margalef index. The obtained data suggest that in northeast Ukraine, the most favourable conditions for the development of corticulous myxomycetes are those particular species of substrate-forming plants. The appropriateness of these species for the development of myxomycetes in the conditions of the Holarctic had not been shown earlier (Stephenson et al., 2001; Yatsuk et al., 2018).

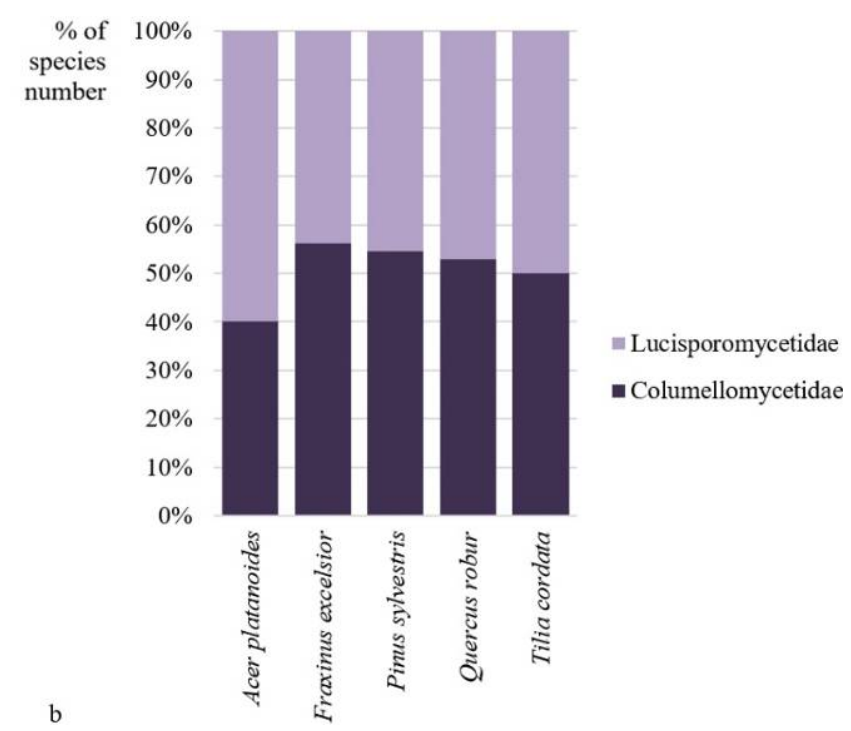

Fig. 4. Shares of above-species taxa of myxomycetes according to the number of species $(\mathrm{n}=38)$ on different substrate-forming plants: $a$-ratios between the orders, $b$-ratios between the subclasses

Calculations revealed only insignificant differences in taxonomic spectra of myxomycetes on the bark of the examined species of plants, and this observation makes the taxonomic spectra of corticulous myxomycetes considerably different from the similar spectra developed for the myxomycetes in general (Romanenko, 2002; Leontyev et al., 2006a, 2011). However, we should note the fact that the Physarales were best represented in the taxonomic spectrum of the consortia of $F$. excelsior and A. platanoides, but were completely absent on $P$. sylvestris. This agrees with the earlier published data (Everhart et al., 2008; Novozhilov et al., 2017a) that the distribution of Physarales is limited by acidity of the substrate, because sporocarps of this group contain limey deposits. Since $\mathrm{pH}$ of the bark of $P$. sylvestris (4.3) was the lowest among the compared species, and the highest values (5.9) is typical for $F$. excelsior and $A$. platanoides (Leontyev, 2006a), this observation may be explained by the difference between the substrate-forming plants according to this parameter.

The pattern of the proportions between the subclasses of myxomycetes according to the number of species on different substrates is currently studied poorly, first of all due to the fact that the classification that divides myxomycetes into subclasses Bright-spored (Lucisporomycetidae) and Dark-spored (Columellomycetidae) based on molecular-phylogenic data has developed recently (Fiore-Donno et al., 2013; Leontyev et al., 2019). Today it is clear that the abovementioned subclasses comprise independent phylogenetic branches of myxomycetes that had evolved in the early Paleozoic period (Fiore-Donno et al., 2012) and have underwent individual adaptations to the terrestrial ecosystems, particularly the abilities to develop on the bark of trees (Stephenson et al., 2008; Leontyev \& Schnittler, 2017). The relative contribution of these groups to the consortia of myxomycetes is therefore fundamental for understanding the evolution of the entire class (Rojas \& Stephenson, 2017). Currently, the prevalence of dark-spored myxomycetes in the groups of nivicolous (Novozhilov et al., 2013; Novozhilov et al., 2017b) and litter (Takahashi \& Hada, 2012; Macabago et al., 2017) myxomycetes is well-known, as well as dominance of bright-spored species in the xylophilous group (Takahashi, 2004; Takahashi \& Harakon, 2012). As for corticulous myxomycetes, such an analysis has not been conducted in the studies we are aware of. The obtained results indicate that even between such ecologically close species as
A. platanoides and F. excelsior, the bark of which is very similar according to the texture and physical-chemical properties (Romanenko, 2002; Leontyev, 2006a), there may be differences between the ratio of brightand dark-spored myxomycetes.

An important conclusion that can be drawn from the obtained results is the necessity of separate consideration of the number of observations and sporocarps as two independent, but related parameters of myxomycete abundance. Species that were represented by the highest number of observations may be characterized as the commonest, i.e. such that occur most often and are characterized by broad ecological optimum, particularly concerning the type of substrate and the parameters dependent on it, as $\mathrm{pH}$ (Romanenko, 2002; Everhart et al., 2008), hygroscopy (Romanenko, 2002; Schnittler et al., 2016), age of the plants and sampling height (Ing, 1994; Schnittler et al., 2016). Unlike the previous parameter, the number of sporocarps characterizes not the distribution, but the intensity of the development in favourable conditions (which may occur in the territory relatively seldom). We may assume that abundant species do not necessarily demonstrate a broad range of ecological tolerance. Particularly, Schnittler et al. (2016) found that some abundant species of myxomycetes (Echnostelium brooksi, E. fragile) have narrow substrate specialization. This observation is confirmed by our data about significant differences between A. cinerea, E. elachiston, L. kleisobolus, L. operculata, E. papillatum and the remaining examined species according to the ratios between the number of observations and the number of sporocarps. All the indicated species developed massive sporulation only in favourable conditions and were not among the leaders by the number of observations.

\section{Conclusion}

The data we obtained indicate the presence of specific complexes of corticulous myxomycetes associated with leading species of substrateforming plants. This allows us to confirm the conclusion drawn by Schnittler et al. (2016) that the distribution of corticulous myxomycetes is limited by the presence of appropriate substrate rather than their ability to spread. Differences that we found include the species composition, abundance of some species, the number of positive moist chambers, taxonomic structure of the consortia at the levels of orders and subclasses, i.e. practi- 
cally all the parameters involved in the study. In the light of the obtained data, the conclusions about the determining role of physical-chemical properties of substrates on the formation of myxomycete biota, made by other scientists, need elaboration, because the differences in the composition of myxomycetes were determined even between the plants that have very similar texture, $\mathrm{pH}$ and hygroscopicity of the bark (A. platanoides, F. excelsior). However, it has to be noted that the mentioned patterns were confirmed only for those species of plants for which we managed to collect the representative material (over 1,000 sporocarps and over 5 species of myxomycetes). This encourages studies of myxomycete consortia on other species of trees distributed in the northeast of Ukraine.

\section{References}

Adl, S. M., Bass, D., Lane, C. E., Lukeš, J., Schoch, C. L., Smimov, A., Agatha, S., Berney, C., Brown, M. W., Burki, F., Cárdenas, P., Čepička, I., Chistyakova, L., Campo, J., Dunthom, M., Edvardsen, B., Eglit, Y., Guillou, L., Hampl, V., Heiss, A. A., Hoppenrath, M., James, T. Y., Karpov, S., Kim, E., Kolisko, M., Kudryavtsev, A., Lahr, D. J. G., Lara, E., Le Gall, L., Lynn, D. H., Mann, D. G., Massana i Molera, R., Mitchell, E. A. D., Morrow, C., Park, J. S., Pawlowski, J. W., Powell, M. J., Richter, D. J., Rueckert, S., Shadwick, L., Shimano, S. Spiegel, F. W., Torruella i Cortes G., Youssef, N., Zlatogursky, V., \& Zhang, Q. (2019). Revisions to the classification, nomenclature, and diversity of Eukaryotes. Joumal of Eukaryotic Microbiology, 66(1), 4-119.

Aguilar, M., Fiore-Donno, A. M., Lado, C., \& Cavalier-Smith, T. (2014). Using environmental niche models to test the 'everything is everywhere' hypothesis for Badhamia. International Society for Microbial Ecology Journal, 8, 737-745.

Barbarych, A. I. (Ed.). (1977). Geobotanichne rajonuvannja Ukrajins'koji RSR [Geobotanical Zonation of the Ukrainian SSR]. Naukova Dumka, Kyiv (in Ukrainian).

Borg Dahl, M., Brejnrod, A. D., Russel, J., Sørensen, S. J., \& Schnittler, M. (2019). Different degrees of niche differentiation for bacteria, fungi, and myxomycetes within an elevational transect in the German Alps. Microbial Ecology, 78(3), $764-780$.

Clark, J., \& Haskins, E. F. (2013). The nuclear reproductive cycle in the myxomycetes: A review. Mycosphere, 4(2), 233-248.

Everhart, S. E., Ely, J. S., \& Keller, H. W. (2009). Evaluation of tree canopy epiphytes and bark characteristic associated with the presence of corticolous myxomycetes. Botany, 87, 509-517.

Everhart, S. E., Keller, H. W., \& Ely, J. S. (2008). Influence of bark pH on the occurrence and distribution of tree canopy myxomycete species. Mycologia, 100, 191-204.

Fiore-Donno, A. M., Clissmann, F., Meyer, M., Schnittler, M., \& Cavalier-Smith, T. (2013). Two-gene phylogeny of bright-spored myxomycetes (slime moulds, superorder Lucisporidia). PLoS One, 8, e62586.

Fiore-Donno, A. M., Kamono, A., Meyer, M., Schnittler, M., Fukui, M., \& CavalierSmith, T. (2012). 18S rDNA phylogeny of Lamproderma and allied genera (Stemonitales, Myxomycetes, Amoebozoa). PLoS One, 7, e35359.

Fiore-Donno, A. M., Weinert, J., Wubet, T., \& Bonkowski, M. (2016). Metacommunity analysis of amoeboid protists in grassland soils. Scientific Reports, 6 , e19068.

Goad, A. E., \& Stephenson, S. L. (2013). Myxomycetes appearing in moist chamber cultures on four different types of dead leaves. Mycosphere, 4, 707-712.

Godsil, C., \& Royle, G. (2001). Algebraic graph theory. Springer-Verlag, New York.

Gotelli, N. J., \& Chao, A. (2013). Measuring and estimating species richness, species diversity, and biotic similarity from sampling data. In: Encyclopedia of biodiversity. New York, Amsterdam, Elsevier. Pp. 195-211.

Heluta, V. P. (1989). Flora gribov Ukrainy. Muchnistorosyanye griby [Fungal Flora of Ukraine. Downy Mildew Fungi]. Naukova Dumka, Kyiv (in Ukrainian).

Ing, B. (1994). The phytosociology of myxomycetes. New Phytologist, 126, 175-201.

Kang, S., Tice, A. K., Spiegel, F. W., Silberman, J. D., Pánek, T., Cepicka, I., Kostka, M., Kosakyan, A., Alcântara, D. M. C., Roger, A. J., Shadwick, L. L., Smirnov, A., Kudryavtsev, A., Lahr, D. J. G., \& Brown, M. W. (2017). Between a pod and a hard test: The deep evolution of amoebae. Molecular Biology and Evolution, 34(9), 2258-2270.

Leontyev, D. V. (2006a). Vidovoj sostav miksomitsetov (Myxomycota) Natsionalnogo Prirodnogo Parka "Gomolshnaskie Lesa" (Ukraina) [Species composition of Myxomycota in Gomolsha Forests National Nature Park (Ukraine)]. Mikologiya i Fitopatologiya, 40(2), 101-107 (in Russian).

Leontyev, D. V. (2006b). Novye dlya Ukrainy vidy miksomitsetov (Myxomycota) [New records of myxomycetes in Ukraine (Myxomycota)]. Mikologiya i Fitopatologiya, 40(3), 218-230 (in Russian).

Leontyev, D. V., \& Fefelov, K. A. (2012). Nomenclatural status and morphological notes on Tubifera applanata sp. nov. Mycotaxon, 120(2), 247-251.

Leontyev, D. V., \& Schnittler, M. (2017). Phylogeny of myxomycetes. In: Myxomycetes. Biology, systematics, biogeography and ecology. Rojas Alvarado, C., \& Stephenson, S. L. (Ed.). New York, Amsterdam, Elsevier. Pp. 83-106.
Leontyev, D. V., Dudka, I. O., Kochergina, A. V., \& Kryvomaz, T. I. (2012). New and rare myxomycetes of Ukraine 3. Forest and forest-steppe zone. Nova Hedwigia, 94, 335-354.

Leontyev, D. V., McHugh, R., Fefelov, K. A., \& Kochergina, A. V. (2011). New and rare myxomycetes of Ukraine 2. South-West Crimea. Nova Hedwigia, 92, 245-256.

Leontyev, D. V., Schnittler, M., \& Stephenson, S. L. (2014). Pseudocapillitium or true capillitium? A study of capillitial structures in Alwisia bombarda (Myxomycetes). Nova Hedwigia, 99, 441-451.

Leontyev, D. V., Schnittler, M., Stephenson, S., Novozhilov, Y. K., \& Shchepin, O. V. (2019). Towards a phylogenetic classification of myxomycetes. Phytotaxa, 399, 209-238.

Leontyev, D. V., Yatsiuk, I. I., \& Kochergina, A. V. (2020). Vkliuchennia miksomitsetiv do Chervonoi Knyhy Ukrainy: Dotsilnist, kryterii vidboru ta rekomendovani vydy [Inclusion of myxomycetes in the Red Data Book of Ukraine: Feasibility, selection criteria and recommended species]. Ukrainian Botanical Journal, 77(3), 189-203 (in Ukrainian).

Macabago, S. A. B., Dagamac, N. H. A., dela Cruz, T. E. E., \& Stephenson, S. L. (2017). Implications of the role of dispersal on the occurrence of litter-inhabiting myxomycetes in different vegetation types after a disturbance. Nova Hedwigia, $104,221-236$.

Mitchell, D. W. (2004). A key to corticolous Myxomycota. Systematics and Geography of Plants, 74, 261-285.

Novozhilov, Y. K., Rollins, A. W., \& Schnittler, M. (2017a). Ecology and distribution of myxomycetes. In: Myxomycetes. Biology, systematics, biogeography and ecology. Rojas Alvarado, C., \& Stephenson, S. L. (Ed.). New York, Amsterdam, Elsevier. Pp. 253-297.

Novozhilov, Y. K., Schnittler, M., Erastova, D. A., \& Schepin, O. N. (2017b). Myxomycetes of the Sikhote-Alin State Nature Biosphere Reserve (Far East, Russia). Nova Hedwigia, 104, 183-209.

Novozhilov, Y. K., Schnittler, M., Erastova, D. A., Okun, M. V., Schepin, O. N., \& Heinrich, E. (2013). Diversity of nivicolous myxomycetes of the Teberda State Biosphere Reserve (Northwestern Caucasus, Russia). Fungal Diversity, 59, 109-130.

Novozhilov, Y. K., Zemlianskaia, I. V., Schnittler, M., \& Stephenson, S. L. (2006). Myxomycete diversity and ecology in the arid regions of the Lower Volga River Basin (Russia). Fungal Diversity, 23, 193-241.

Poulain, M., Meyer, M., \& Bozonnet, J. (2011). Les myxomycètes. DauphinéSavoie, Sarl Editions.

Prylutskyi, O. V., Akulov, O. Y., Leontyev, D. V., Ordynets, O. V., Yatsiuk, I. I., Usichenko, A. S., \& Savchenko, A. O. (2017). Fungi and fungus-like organisms of Homilsha Forests National Park, Ukraine. Mycotaxon, 132(3), 1-56.

Ricotta, C., \& Podani, J. (2017). On some properties of the Bray-Curtis dissimilarity and their ecological meaning. Ecological Complexity, 31, 201-205.

Rojas, C., \& Stephenson, S. L. (Eds.). (2017). Myxomycetes. Biology, systematics, biogeography and ecology. New York, Amsterdam, Elsevier.

Rollins, A. W., \& Stephenson, S. L. (2011). Global distribution and ecology of myxomycetes. Current Topics in Plant Biology, 12, 1-14.

Romanenko, K. O. (2002). Miksomitsety osnovnykh roslynnykh uhrupovan Krymskoho pryrodnoho zapovidnyka [Myxomycetes of the main plant communities of the Crimea Nature Reserve]. Ukrainian Botanical Journal, 59(6), 730-736 (in Ukrainian).

Schnittler, M., Dagamac, N. H. A., Sauke, M., Wilmking, M., Buras, A., Ahlgrimm, S., \& Eusemann, P. (2016). Ecological factors limiting occurrence of corticolous myxomycetes - a case study from Alaska. Fungal Ecology, 21, 16-23.

Schnittler, M., Novozhilov, Y. K., Shadwick, J. D. L., Spiegel, F. W., García-Carvajal, E., \& König, P. (2015). What substrate cultures can reveal: Myxomycetes and myxomycete-like organisms from the Sultanate of Oman. Mycosphere, 6, 356-384.

Schnittler, M., Unterseher, M., \& Tesmer, J. (2006). Species richness and ecological characterization of myxomycetes and myxomycete-like organisms in the canopy of a temperate deciduous forest. Mycologia, 98, 223-232.

Shchepin, O. N., Schnittler, M., Erastova, D. A., Prikhodko, I. S., Borg Dahl, M., Azarovd, D. V., Chernyaeva, E. N., \& Novozhilov, Y. K. (2019). Community of dark-spored myxomycetes in ground litter and soil of taiga forest (NizhneSvirskiy Reserve, Russia) revealed by DNA metabarcoding. Fungal Ecology, 39, 80-93.

Spiegel, F. W., Stephenson, S. L., Keller, H. W., Moore, D. L., \& Cavender, J. C. (2004). Mycetozoans. In: Biodiversity of Fungi. Inventory and monitoring methods. Mueller, G. M., Bills, G. F., \& Foster, M. S. (Eds.). Amsterdam, Elsevier, Academic Press. Pp. 547-576.

Stephenson, S. L., \& Schnittler, M. (2017). Myxomycetes. In: Handbook of the protists. Archibald, J. M., Simpson, A. G. B., Slamovits, C. H., Margulis, L., Melkonian, M., Chapman, D. J., \& Corliss, J. O. (Ed.). Springer, New York. Pp. 1405-1432.

Stephenson, S. L., Schnittler, M., \& Novozhilov, Y. K. (2008). Myxomycete diversity and distribution from the fossil record to the present. Biodiversity and Conservation, $17,285-301$. 
Stephenson, S. L., Schnittler, M., Mitchell, D. W., \& Novozhilov, Y. K. (2001). Myxomycetes of the Great Smoky Mountains National Park. Mycotaxon, 78, 1-15.

Takahashi, K. (2004). Distribution of myxomycetes on different decay states of deciduous broadleaf and coniferous wood in a natural temperate forest in the southwest of Japan. Systematics and Geography of Plants, 74, 133-142.

Takahashi, K., \& Hada, Y. (2012). Seasonal occurrence and distribution of myxomycetes on different types of leaf litter in a warm temperate forest of Western Japan. Mycoscience, 53, 245-255.

Takahashi, K., \& Harakon, Y. (2012). Comparison of wood-inhabiting myxomycetes in subalpine and montane coniferous forests in the Yatsugatake Mountains of Central Japan. Journal of Plant Research, 125, 327-337.
Urich, T., Lanzén, A., Qi, J., Huson, D. H., Schleper, C., \& Schuster, S. C. (2008). Simultaneous assessment of soil microbial community structure and function through analysis of the metatranscriptome. PLoS One, 3, e2527.

Vlasenko, A. V., Novozhilov, Y. K., Asbaganov, S. V., \& Dejidmaa, T. (2020). Methods and difficulties of identifying species in studies on the ecology and distribution patterns of spore organisms. Contemporary Problems of Ecology, 13(4), 346-359.

Yatsiuk, I. I., Leontyev, D. V., \& Shlakhter, M. (2018). Myxomycetes of National Nature Park Slobozhanskiy (Ukraine): Biodiversity and noteworthy species. Nordic Journal of Botany, 1, e01605. 